JURNAL ILMIAH KEBIDANAN IMELDA

Vol.6, No.2, September 2020, pp.73-76

ISSN: 2597-7180 (Online),2442-8116 (Print)

\title{
PENGARUH HYPNOBREASFEEDING TERHADAP PRODUKSI VOLUME ASI IBU NIFAS DI RUMAH SAKIT IMELDA PEKERJA INDONESIA MEDAN
}

\author{
Wellina BR Sebayang1, Carolina Theresia Simanjuntak ${ }^{2}$ \\ Universitas Imelda Medan, Indonesia
}

\begin{tabular}{l}
\hline \hline Article Info \\
\hline Article history: \\
Received Sep 22, 2019 \\
Revised Sep 24, 2020 \\
Accepted Sep 25, 2020
\end{tabular}

Keywords:

Hynobreastfeeding

Increased volume of breast milk

Postpartum mother

\begin{abstract}
Hypnobreasfeeding is a natural attempt to instill the intention into our subconscious mind, to produce sufficient milk for the benefit of the baby. Increase the amount of breast milk by convincing yourself that the amount of breast milk is sufficient to meet the baby's needs exclusively without the addition of formula milk. The purpose of this study was to determine the effect of hypnobreasfeeding on the volume production of postpartum mother's milk at the Imelda Hospital Workers Indonesia. This study used an observational analytic method with a cross sectional approach. The subjects in this study were 20 people. This research was conducted at the Imelda Indonesian Workers Hospital in Medan from January to October 2017. The sampling method was the total sample. Data analysis used the mean Whytney statistical test with statistical significance of $p$ value 0.05 . Based on the results of data analysis, it was found that in the intervention group $90 \%$ of respondents experienced an increase in the volume of breast milk in the category of sufficient milk. In the control group, only $50 \%$ were in the category of sufficient breastfeeding, while $50 \%$ had given formula milk to their babies. There is an increase in the volume of breast milk after hynobreastfeeding. The conclusion is that there is a hynobreastfeeding effect on the increase in the volume of breast milk for post-partum mothers at the Imelda Hospital, Indonesian Workers, Medan. The suggestion of this research is to increase hypnobreasfeeding socialization and further research with a different design.
\end{abstract}

This is an open access article under the CC BY-SAlicense.

This is an open access article under the CC BY-SAlicense.
Corresponding Author:
Wellina BR Sebayang,
Program Studi D-III Kebidanan,
Universitas Imelda Medan,
Jl. Bilal No. 52 Kelurahan Pulo Brayan Darat I Kecamatan Medan Timur, Medan - Sumatera Utara.
Email: wellinasebayang@gmail.com

\section{INTRODUCTION}

Sustainable Development Goals dalam the 2030 Agenda for sustainable development menargetkan pada tahun 2030 dapat mengurangi angka kematian neonatal paling sedikit 12 per 1.000 kelahiran hidup dan kematian pada anak dibawah usia 5 tahun paling sedikit 25 per 1.000 kelahiran hidup. Hal tersebut dapat dicapai salah satunya dengan pemberian ASI eksklusif dilaksankan dengan baik (United Nations). Namun hanya $44 \%$ dari bayi lahir didunia yang mendapat ASI dalam waktu satu jam pertama sejak lahir, bahkan masih sedikit bayi di bawah usia 6 bulan disusui secara eksklusif di Afrika Tengah sebanyak 25\%, Amerika Latin dan Karibia sebanyak 32\%, Asia Timur sebanyak 30\%, Asia Selatan sebanyak 47\% dan negara berkembang sebanyak 46\%. Secara keseluruhan, kurang dari $40 \%$ anak di bawah usia 6 bulan pertama sampai paling sedikit 50\%. Ini merupakan target kelima WHO di tahun 2025. 
Di Indonesia, bayi yang telah mendapatkan ASI eksklusif sampai usia 6 bulan adalah sebesar 29,5\% (Profil Kesehatan Indonesia, 2017). Hal ini belum sesuai dengan target Rencana Strategis Kementrian Kesehatan tahun 2015-2019 yaitu persentase bayi usia kurang dari 6 bulan yang mendapatkan ASI eksklusif sebesar $50 \%$.

Menurut Provinsi, cakupan ASI ekslusif pada bayi sampai usia enam bulan paling rendah berada di Sumatera Utara sebesar 12,4 \%, Gorontalo sebesar 12,5\% dan paling tinggi di DI Yogyakarta sebesar 55,4\%. Sementara kondisi Sumatera Barat didapatkan pemberian ASI Eksklusif sampai usia 6 bulan sebesar 37,6\% (Data dan Informasi Profil Kesehatan Indonesia, 2017).

Data kementrian kesehatan mencatat angka inisiasi menyusui dini (IMD) di Indonesia meningkat dari $51,8 \%$ pada 2016 menjadi $57,8 \%$ pada tahun 2017. Kendati meningkat angka itu disebut masih jauh dari target sebesar 90\%. Kenaikan yang sama juga terjadi pada angka pemberian ASI eksklusif dari 29,5\% pada 2016 menjadi 35,7\% pada 2017. Angka ini juga terbilang sangat kecil jika mengingat pentingnya peran ASI bagi kehidupan bayi.

Hasil dari Survey Data dan Kesehatan Indonesia (SDKI) pada tahun 2017 menunjukkan praktik pemberian ASI bayi berumur dibawah 6 bulan adalah 52\%. Persentase ASI eksklusif menurun seiring dengan bertambahnya umur bayi, dari $67 \%$ pada umur 0sampai1 bulan, menjadi 55\% pada umur 2 sampai 3 bulan, $38 \%$ pada umur 4 sampai 5 bulan (SDKI, 2017). Cakupan bayi yang mendapatkan ASI secara nasional sebesar $61,33 \%$. Angka tersebut sudah melampaui target Rencana Strategi (Renstra) pada beberapa provinsi tahun 2017 yaitu 44\%. Provinsi Sulawesi utara berada diurutan ke-2 terendah dari 34 provinsi yang ada di Indonesia dengan cakupan yang mendapat ASI eksklusif yaitu 38,69\% (Kemenkes, 2018).

Menurut penelitian tentang Hypnobreasfeeding menyatakan bahwa Hypnobrastfeeding mampu meningkatkan produksi ASI karena memberikan efek rileks, ketenangan fisik, pikiran, dan kenyamanan pada masa menyusui yang dapat memberikan positif feedback mechanism berupa respon peningkatan pelepasan oksitosin dan prolaktin oleh pituitari. Hormon prolaktin berperan dalam merangsang zat gizi untuk sintesis air susu dalam sel-sel sekretorius alveoli. Oksitosin menyebabkan kontraksi mioepitel di sekeliling alveolus dan mengeluarkan air susu (milk ejection) (Pratiwi et al., 2018). Berdasarkan uraian diatas peneliti tertarik mengambil judul "Pengaruh Hypnobreasfeeding Terhadap Peningkatan Volume ASI pada Ibu Nifas di Rumah Sakit Imelda Pekerja Indonesia".

\section{RESEARCH METHOD}

Jenis penelitian ini merupakanquasi eksperimen menggunakan desain kohort. Sampel dibagi dalam dua kelompok, yaitu kelompok intervensi dan kelompok kontrol. Pada awal penelitian pada kedua kelompok penelitian dilakukan observasi pengeluaran ASI tahap berikutnya: selama empat hari kelompok intervensi diberikan tehnik sugesty hypnobreasfeeding. Pada kelompok kontrol tidak diberikan sugesty hypnobreasfeeding. Pada tahap akhir dilakukan kembali pengukuran pengeluaran ASI, jumlah ASI menggunakan botol ASI. Uji statistik menggunakan uji mean whytney dengan statistik kemaknaan $p$ value 0,05. Populasi adalah ibu nifas baik yang melahirkan normal maupun Sectio Caesarea (SC). Penelitian dilakukan di Rumah Sakit Imelda Pekerja Indonesia Medan dilanjut dengan observasi via Wa dengan responden.

\section{RESULTS AND ANALYSIS}

3.1 Hasil

Distribusi Karakteristik Responden

Tabel 1. Distribusi Frekuensi Karakteristik Responden

\begin{tabular}{llcc}
\hline \multirow{2}{*}{ Karakteristik } & \multicolumn{2}{c}{ Jumlah } \\
\cline { 2 - 4 } & & Frekuensi & Persentase \% \\
\hline \multirow{2}{*}{ Umur } & $<20$ & 3 & 15 \\
\cline { 2 - 4 } & $20-35$ & 13 & 65 \\
\cline { 2 - 4 } & $>35$ & 4 & 20 \\
\hline Paritas & Primipara & 11 & 55 \\
\cline { 2 - 4 } & Multipara & 9 & 65 \\
\hline \multirow{2}{*}{ Pendidikan } & SMA sederajat & 13 & 35 \\
\cline { 2 - 4 } & Universitas & 7 & \\
\hline
\end{tabular}

Data Primer, 2020

Hasil penelitian frekuensi responden ditemukan mayoritas umur 20-35 tahun, primipara dengan riwayat pendidikan SMA sederajat. 
Distribusi Pengaruh Hynobreasfeeding Terhadap Peningkatan Volume Asi

Tabel 2. Distribusi Frekuensi Pengaruh Hynobreasfeeding terhadap peningkatan volume ASI

\begin{tabular}{|c|c|c|c|c|}
\hline \multirow[t]{2}{*}{ Variabel } & \multirow[t]{2}{*}{ Hypnobreasfeeding } & \multicolumn{2}{|c|}{ Produksi ASI } & \multirow[t]{2}{*}{ Nilai $p$} \\
\hline & & Cukup & Kurang & \\
\hline \multirow[t]{2}{*}{ Kelompok } & Intervensi & 8 & 2 & 0,02 \\
\hline & Kontrol & 5 & 5 & \\
\hline
\end{tabular}

Dari hasil penelitian didapatkan bahwa dari 10 kelompok intervensi sebesar $80 \%$ mengalami peningkatan produksi ASI dengan kategori ASI Cukup. Responden kelompok kontrol tanpa mendapat tehnik hypnobreasfeeding hanya 50\% dengan kategori ASI cukup sementara 50\% lagi sudah memberikan susu formula kepada bayinya.

\subsection{Pembahasan}

Hypnobreastfeeding adalah metode yang mampu menciptakan situasi persuatif di alam bawah sadar seseorang sehingga meningkatkan motivasi dan kepercayaan diri untuk memproduksi dan memberikan ASI kepada bayi. Kepercayaan diri ibu bisa dibangun melalui kalimat positif yang diberikan kepada ibu saat ibu sudah dalam kondisi trance yaitu kondisi ibu telah mencapai pikiran alam bawah sadar (Anita, 2017).

Kondisi psikologis yang tidak tenang/stres memicu peningkatan kortisol dan kotekolamin yang dapat menghambat pelepasan prolaktin dan oksitosin. Jika terjadi kondisi sebaliknya yaitu dalam tahap induksi hypnobreastfeeding, efek relaksasi, ketenangan fisik, pikiran, dan kenyamanan dapat diraskaan oleh ibu sehingga terjadi positif feedback mechanism berupa respon peningkatan pelepasan oksitosin dan prolaktin oleh pituitary.

Kalimat-kalimat positif yang diberikan kepada ibu memberi keyakinan dan motivasi semangat sehingga secara otomatis akan meningkatkan produksi ASI. Dengan tehnik sederhana maka metode hypnobreasfeeding dapat memberi pengaruh terhadap peningkatan volume ASI.

\section{CONCLUSION}

Ada pengaruh hypnobreasfeeding terhadap peningkatan volume ASI. Berdasarkan hasil analisa data didapatkan pada kelompok intervensi $90 \%$ responden mengalami peningkatan volume ASI dengan kategori ASI cukup. Pada kelompok control hanya 50\% dengan kategori ASI cukup sementara 50\% lagi sudah memberikan susu formula kepada bayinya. Terdapat peningkatan jumlah volume ASI sesudah melakukan hynobreastfeeding.

\section{REFERENCES}

Anita, R. 2017. Hynpnobreasfeeding untuk meningkatkan produksi ASI pada Ibu menyusui yang bekerja. Jurnal STIKes Patria Husada Blitar.

Badan Penelitian dan Pengembangan Kesehatan Kementrian Republik Indonesia. Jakarta.

Bahriyah, F. 2017. Hubungan Pekerjaan Ibu Terhadap Pemberian Ibu Terhadap Pemberian Asi Ekskusif Pada Bayi. Journal Endurance.

Dewi, U. 2016. Faktor yang Mempengaruhi Praktk Menyusui pada Ibu post Sectio Saecarea Di RSI A. Yani Surabaya. Jurnal lmiah Kesehatan.

Hidayat, A. 2016. Asuhan Kebidanan Persalinan. Yogyakarta: Nuha Medika.

Kementrian Kesehatan Republik Indonesia. 2017. Profil Kesehatan Republik Indonesia. Jakarta. Kemenkes RI.

Kementrian Kesehatan Republik Indonesia. 2017. Riset Kesehatan Dasar. Jakarta: Kemenkes RI.

Kementrian Kesehatan Republik Indonesia. 2018. Survei Data dan Kesehatan (SDKI). Jakarta: Kemenkes RI. Maritalia, D. 2017. Asuhan Kebidanan pada Ibu Nifas. Yogyakarta.

Pratiwi, S. 2018. Pengaruh Hynpnobreasfeeding terhadap produksi ASI. Jurnal Program studi kebidanan STIKes Yarsi Mataram.

Profil Kesehatan Indonesia. 2017. Cakupan ASI Eksklusif. Jakarta.

Profil Kesehatan Tapanuli Utara. 2016. Sumatera Utara.

Ramli, R. 2020. Hubungan Pengetahuan dan Status Pekerjaan Ibu dengan Pemberian ASI Eksklusif. Jurnal Promkes: The Indonesian Journal of Health Promotion and health Education. Sidotopo.

Riset Kesehatan Dasar. 2017. Data dan Informasi Profil Kesehatan Indonesia.

Setia, S. 2018. Hubungan Pekerjaan dan Pendidikan Ibu dengan Pemberian ASI Eksklusif di Wilayah Kerja Puskesmas Hinai Kiri. Jurnal STIKes Putra Abadi Langkat. Sumatera Utara.

Untari, J. 2017. Hubungan Antara Karateristik Ibu Dengan Pemberian ASI Eksklusif Di Wilayah Kerja Di Puskesmas Minggir Kabupaten Sleman. Jurnal Forum Ilmiah KesMas Respati.

Wayan, N. 2016. Hynpnobreasfeeding awali suksesnya ASI Eklusif. Jurnal Dosen Jurusan Kebidanan Politeknik Kesehatan Denpasar. 


\section{BIOGRAPHIES OF AUTHORS}

\begin{tabular}{l|l} 
Wellina BR Sebayang, Gelar D-III diperoleh dari Akademi Kebidanan Imelda Medan, \\
Jurusan Kebidanan pada tahun 2006, Gelar Sarjana diperoleh dari Universitas \\
Padjadjaran Bandung, Jurusan Bidan Pendidik Tahun 2009. Magister Kesehatan \\
diperoleh dari Universitas Sumatera Utara, Jurusan Kesehatan Reproduksi pada tahun \\
2014. Saat ini aktif sebagai dosen tetap di Prodi Kebidanan Universitas Imelda Medan.
\end{tabular}

